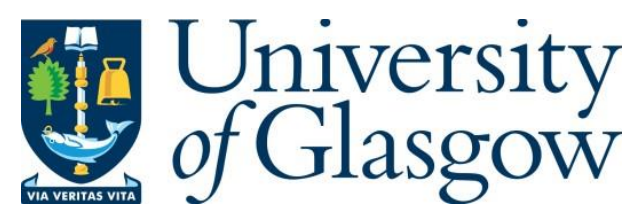

O'Driscoll, C. (2018) The irony of just war? Ethics and International Affairs, 32(2), pp. 227-236. (doi: 10.1017/S0892679418000321).

There may be differences between this version and the published version. You are advised to consult the publisher's version if you wish to cite from it.

http://eprints.gla.ac.uk/160896/

Deposited on: 19 April 2018

Enlighten - Research publications by members of the University of Glasgow

http://eprints.gla.ac.uk 


\section{The Irony of Just War}

Cian O'Driscoll

Contemporary Just War: Theory and Practice, Tamar Meisels (Abingdon: Routledge, 2018), 170 pp., \$155 cloth, \$44.95 paper.

Realist Ethics: Just War Traditions as Power Politics, Valerie Morkevičius (Cambridge: Cambridge University Press, 2018), 268 pp., \$34.99 paper.

Thomas Aquinas on War and Peace, Gregory M. Reichberg (Cambridge: Cambridge University Press, 2017), 326 pp., \$99.99 cloth.

"Our age is involved in irony because so many dreams of our nation have been so cruelly refuted by history. Our dreams of a pure virtue are dissolved in a situation in which it is possible to exercise the virtue of responsibility toward a community of nations only by courting the prospective guilt of the atomic bomb. And the irony is increased by the frantic efforts of some of our idealists to escape this hard reality by dreaming up schemes of an ideal world order which have no relevance to either our present dangers or urgent duties."

-Reinhold Niebuhr ${ }^{1}$

Anyone who has ever engaged with debates bearing on the ethics of war will presumably recognize the old adage, "just war is just war." It tends to get an airing whenever just war theory is discussed in any detail. Critics of just war theory cite it in order to focus attention on what they see as the very real dangers of engaging the just war idiom. By claiming that just war is just war, they are suggesting that just war theory both distracts from and sanitizes the horror of modern warfare by dressing it up in the language of moral principles. This is, to be 
sure, a powerful critique. It frames just war theory as a vapid but also pernicious discourse that ennobles military conflict and thereby renders it more palatable for general consumption. ${ }^{2}$ Indeed, by reminding us of the grim realities of so-called just wars, the phrase punctures the moral pretensions of just war theory, exposing it as so much cant. Just war is, it seems, after all, just war. ${ }^{3}$

There is, however, an irony here. Where the idea that just war is just war is usually invoked to discredit the enterprise of just war theory, it can also be taken as a reminder of why we need it in the first place. Viewed in this light, what is presented as a critique of just war theory is actually better understood as a restatement of its raison d'être. It is precisely because just war is just war, with all that this implies, that we must think so carefully and so judiciously about it. This enjoins, among other things, thinking in a frank and forthright way about what is signified (and putatively justified) by the "war" in "just war."4 My concern, which echoes those of other scholars in the field, is that just war theorists have not always done a good job of this. ${ }^{5}$ One could mount a case, for instance, that the rump of just war scholarship over the past decade has been characterized by disinterest regarding the material realities of warfare. ${ }^{6}$ Is this still the case? This essay examines how, if at all, the idea that just war is just war has been negotiated by surveying a series of benchmark books on the ethics of war published over the past year.

\section{THE VIEW FROM GAZA}

To begin, Contemporary Just War: Theory and Practice, by Tamar Meisels, is an ambitious and interesting book that pursues a dual purpose. On the one hand, it offers a "defense" of Michael Walzer's "traditional” just war theory. On the other, it seeks to extend that theory, now reinforced, to a range of contemporary issues and conflicts that have otherwise largely 
been ignored by just war scholars. A few brief words to describe Meisels's treatment of these objectives will provide a useful platform for the discussion that follows.

Regarding the first objective, Meisels's decision to characterize this book as a defense of Walzer's traditional approach is revealing. It discloses her perception of contemporary just war theory as a "deeply divided" field, with Walzer's theory on the back foot against a "revisionist" alternative that Meisels associates with, among others, Jeff McMahan, Cecile Fabre, and David Rodin (p. 2). As there has already been much written in these pages about the distinction between revisionist and traditionalist approaches to the ethics of war, it will suffice here to note that Meisels pins it to a divergence of views on three key issues: civilian immunity, the moral equality of soldiers, and the independence of the jus ad bellum and jus in bello poles of just war theorizing from one another. Meisels observes that support for the traditional approach to these issues has been waning in recent years, in both theory and practice, and devotes the first three substantive chapters of the book to reaffirming and indeed reinforcing it. Not only are these chapters clearly elucidated and tightly argued, they are also pitched at a level that caters to specialists in the field without forsaking anything in terms of accessibility for a wider readership.

Meisels's second objective, which she pursues in the latter half of the book, is to apply Walzer's framework to a set of issues that have so far been overlooked by just war theorists. The issues she alights upon are ones that have arisen in the context of what Meisels calls 'the Israeli experience", by which she means Israel's precarious position in the Middle East and the ever-present danger of war with its neighbors in Gaza, Iran, and Syria that confronts it (p. 3). This is an experience that Meisels, who is a professor at Tel Aviv University, knows all too well. Accordingly, there are chapters devoted to examining how militaries should balance proportionality and risk in asymmetric conflicts, economic warfare and blockades, anticipatory defense, and targeted assassination. These discussions are 
illuminating and will provide rich fodder for just war theorists, as well as excellent teaching material for the classroom. Interestingly, although Meisels relies primarily on Walzer's framework to shed light on these issues, she also incorporates insights from the revisionist school into her analysis. She does so, not by seeking to develop some synthesis or fusion of horizons between the two approaches, but simply by using each to examine the propositions the other brings forth. The result is a thoughtful, pluralist, and incisive set of discussions that bring one major point of interest to the fore.

This point of interest derives from Meisels's focus on the Israeli experience. As noted above, Israel's history of violent conflict is not merely a matter of remote academic interest for Meisels, it is the backcloth to her everyday life. When she discusses the targeting of Iranian nuclear scientists by Mossad agents or the tactics employed by the Israeli Defence Force to counter rocket-fire emanating from Gaza, she is addressing issues that she obviously cares deeply about, and, crucially, has observed at close quarters (p. xi). This matters insofar as it is presumably this proximity to the frontline that accounts for her determination to treat what she calls "the unfortunate reality of war," rather than its representation in the popular imagination (p. 159). Thus, instead of basing her analysis on the Hollywood vision of warfare - that is, on an agonal world of large-scale pitched battles and the clash of state armies - she focuses on the less romantic but equally deadly actuality of economic sanctions, kill-chains, and counter-insurgency operations.

This focus on the realities of war should not be interpreted as secondary to the theoretical contribution Meisels seeks to make in this book; rather, it is integral to it. Insofar as she frames her book in terms of the theoretical dispute between traditionalist and revisionist approaches to just war, she depicts this rift as hinging on the different ways in which war is posited in these schools of thought. As she presents it, whereas traditionalists base their just war theory on a plausible account of war, revisionist reasoning rests on a 
flawed understanding of war (pp. p. 14-15, 34-35, 45, 152). This flawed understanding comprises two dimensions, one conceptual and the other empirical. The conceptual dimension pertains to the revisionists' predilection to view war as a realm of individual rather than collective agency. Meisels notes the arguments that revisionists proffer for apprehending war in this way and dismisses them. She contends that the revisionist just war theory is premised upon a set of domestic analogies (e.g., to disputes between individuals in civil society or cases of armed robbery) that simply do not reflect the collective and indeed uncivil realities of war (pp. 18, 34, 45). Thus configured, revisionist just war theory is primed for failure. The empirical dimension reflects the revisionists' apparent inability to look beyond the Hollywood vision of war. The charge intimated here is that, to the degree that it addresses warfare at all, revisionist theorizing is indexed to an outmoded, agonal, classical inter-state vision of warfare that bears little relation to the asymmetric realities of contemporary armed conflict. This is a contingent point, and it strikes me that many revisionists would have grounds to refute it. Yet it also suggests a novel insight, namely, that the claim that how we think about "war" primes how we think about "just war" has both an empirical and a theoretical dimension.

There is, however, an element of narrowness to Contemporary Just War. Consider, for example, the frame of reference it adopts for just war theorizing. Walzer's just war theory is introduced as the traditional account of just war with scant reference made to the deeper tradition of just war thinking that is often traced to antiquity. As such, the "revisionist" character of Walzer's own enterprise is overlooked. ${ }^{7}$ The only exception to this occurs in the introduction, where Meisels briefly cites the writings of Francisco de Vitoria and his contemporary interpreter, Gregory M. Reichberg. This is, however, a very minor point, and does not detract from the overall quality of the book. 


\section{Get ReAL}

The second book under consideration here is Realist Ethics: Just War Traditions as Power Politics, by Valerie Morkevičius - a work that I suggest is best read as an extended meditation on the notion that just war is in fact just war. The story Morkevičius tells begins in the early 2000s, when she was a "naïve" doctoral candidate at the University of Chicago, working on just war theory under the supervision of, on the one hand, one of the most prominent scholars in the field, the late Jean Bethke Elshtain, and, on the other, the doyen of offensive realism, John Mearsheimer (p. 3). Morkevičius's world was rocked in 2003, not just by the invasion of Iraq but by the fact that this war, which she vehemently opposed, was supported by a number of high-profile just war theorists, Elshtain included, and opposed by several died-in-the-wool realists, Mearsheimer among them. How had it come to pass that just war theory, which Morkevičius had always associated with the restraint of war, now appeared more bellicose than the doctrine of realpolitik espoused by Mearsheimer and company? Realist Ethics reflects her efforts to discover an answer to that question. The answer she arrives at, and which is set out in a pleasingly avuncular manner over the course of the book, comprises two principal claims: first, that contemporary just war theory has, to its detriment, fallen in thrall to a crusading brand of liberal internationalism; and second, that this situation can be best remedied by re-connecting just war theory to its roots in realist thought (p. 6-7, 58, 196).

The claim that just war theory is in hock to liberal internationalism is a familiar refrain. It recalls A. J. P. Taylor's waspish remark that while realists of the nineteenth century "fought 'necessary' wars, and killed thousands, the idealists of the twentieth century fight 'just' wars and kill millions." "It also resonates with recent arguments by Nicholas Rengger and Maja Zehfuss that the problem with contemporary just war theory is that it is yoked to a 
form of do-gooder liberal sentiment that mistakenly supposes war can be a force for good in the world. ${ }^{9}$ Although their arguments emphasize different points, these authors invoke the same critical insight that just war is just war to debunk the jejune belief that the use of force can ever make the world a better place. Rengger and Zehfuss are in agreement: no matter how well intentioned they may be, or how justified they are, just wars, like all other wars, are necessarily a terrible thing. To the degree that the notion of just war has any validity — and Zehfuss doubts that it does - it can only be as a via negativa, that is, as a remedial measure that is intended to halt even more terrible things from occurring. Although Morkevičius occasionally puts matters slightly differently, this is, I think, her general position too (p. 3839).

Morkevičius's second claim, that the best way to rescue just war theory from liberal internationalism is by resurrecting its "embedded realism," is intriguing. It supposes that the facile attitude to the use of force that taints contemporary just war theory can be rectified by reviving the realist impulse that has historically been a central feature of just war thought, but which has recently fallen into abeyance. This will involve not only acknowledging that just war is just war, but also confronting the implications of this insight. Morkevičius thus makes the case that, instead of negating just war theory, the insight that just war is just war is necessary for its recovery as a "critical tradition" (p. 7).

The way that Morkevičius develops this argument is fascinating. She approaches the idea of just war from a comparative perspective, which is especially important. Instead of focusing narrowly on the Western conception of just war, she incorporates its Islamic and Hindu counterparts into her analysis. This allows her to both broaden and deepen our understanding of just war, while also undercutting the charge that just war is quintessentially a Western construct. The rigor of Morkevičius's scholarship is exemplary, with her treatment of Hindu just war thought a real highlight. 
There are of course aspects of the book that could be critiqued. The discussion of realism, for instance, could be construed as a little on the thin side as it is heavily dependent upon how realist ideas have been developed in International Relations theory, rather than in political thought more generally. ${ }^{10}$ Beyond this, there are two aspects of the argument that I think should have been developed further. The first of these is not so much a new point as an extension of the previous one, as it pertains to Morkevičius's synopsis of realism. Because her preference is to distill realism into a set of core tenets, she privileges consensus over plurality, which in turn leads her to overlook disagreements among realists. This approach has the effect of granting a certain degree of prominence to the voices of mainstream realists, like Mearsheimer, while giving short shrift to those who might not be quite so familiar, but who nevertheless have much to teach us. Where, for instance, are the "righteous realists" that Joel Rosenthal wrote about in his book on realist ethics? ${ }^{11}$

The second aspect of the argument that could have been developed further is the relationship between just war and realism. The issue here is that Morkevičius only gives one side of the story. While she is correct to highlight the "parallels" between realism and just war thinking, it would have been helpful to hear more about the differences between these two traditions. Are there, for instance, pressure points that bring their differences to the surface? The answer to this question is presumably yes, with the issue of preventive war a prime contender. Realists and just wat theorists have historically differed on this issue, with the former willing to countenance it in certain conditions, and the latter strictly opposed to it. Indeed, many just war theorists - though not Elshtain — opposed the 2003 Iraq War on the basis that it was, in their eyes, a preventive war. The structure of Morkevičius' discussion does not, however, permit for any discussion of such issues. This is a pity, but it does not tarnish what is otherwise a wonderfully insightful and thought-provoking book. 


\section{When Thomas Met JeFF}

The final book is Thomas Aquinas on War and Peace, by Gregory M. Reichberg. This is, simply put, one of the best books on the ethics of war to emerge in the past decade, and it should be essential reading for every scholar interested in just war theory. Lest there be any confusion, when I write "every scholar," this is not shorthand for "every historian of the just war tradition," or "every exegete of Thomas Aquinas." The title of the book is unhelpful in this regard: it lends the impression that this is a book with a very narrow or even arcane focus. This could not be further from the truth. The book does not treat the analysis of Aquinas's writings on just war as an end in itself, but rather as a springboard for a farreaching yet incisive account of just war theorizing from the Middle Ages right up to the present day. Accordingly, when I write that this book is essential reading for every scholar interested in just war theory, this is exactly what I mean.

The book is divided into two distinct parts. The first examines Aquinas's just war theory in light of the seedbed from which it grew. This involves a close reading of Aquinas's famous "Quaestio de Bello" that treats it not as a stand-alone piece of casuistry, but as embedded in the systematic treatment of the virtues developed in Aquinas's Summa Theologiae. Sticking with the horticultural metaphor, the second part of the book examines the various offshoots that sprouted from Aquinas's account of just war theory. This embraces a discussion of how certain core aspects of Aquinas's just war theory have been interpreted (and contested) down the years, as well as an extension of his framework to contemporary debates and issues in just war theory.

As a treatment of medieval just war thought, this book stands comfortably alongside landmark works by James Turner Johnson and Frederick Russell. ${ }^{12}$ Like Johnson and Russell, Reichberg does a fine job explaining the background assumptions of medieval political 
thought. Even so, the layered nature of this material means that it is not easy reading. In that regard, nonspecialist readers may benefit from referencing a companion piece, such as the volume Medieval Foundations of International Relations, edited by William Bain. ${ }^{13}$ That book gives an accessible account of medieval political thought and the role it played in shaping the development of just war theory, and indeed modern understandings of international relations, Medieval Foundations of International Relations, edited by William Bain, offers an excellent companion-piece. It brings together chapters by leading experts in the field, among them the aforementioned Johnson and Rengger, as well as Joseph Canning, James Muldoon, Francis Oakley, and Adrian Pabst, to excavate the intellectual frameworks that informed medieval political thought and, by extension, the advent of what is today called International Political Theory. The agenda set out by Bain and his collaborators is valuable in its own right, but, more relevantly for present purposes, it also provides helpful cues for thinking about how Reichberg, and indeed Aquinas, negotiate the "war" in "just war."

Aquinas's definition of war proceeds from an account of peace, not vice versa. That is to say, he defines war not as an ontological category in its own right, but as a rupture of peace, where peace is assumed to be the background condition of human affairs. So far, then, as thinking about just war entails thinking about war, it is ultimately, for Aquinas, derivative of thinking about peace. Anchored in this way, the idea of just war assumes a conservative or reactive complexion. It is not a progressive enterprise, but instead resembles "a protective (and restorative measure), exercised by and for temporal society, against grave violations of the peace." Aquinas's understanding of just war, Reichberg elaborates, has "meaning only against the backdrop of prior wrongdoing, whereby the fabric of concord has been torn" ( $p$. 40). This is interesting insofar as it reminds us that even though Aquinas thought that war could be justified in certain circumstances, he did not necessarily think it was a good thing, or something to be celebrated. Rather, it was always a symptom of a prior failure of politics. 
This basic framing generated a host of debates down the years about how best to understand the character or modality of just war. Is just war akin to an act of punishment or law enforcement? What is its relation to the right to defensive force? Can offensive war also be a just war? Is just war inherently punitive? Or should it be understood more broadly in relation to the vindication of rights? In the course of teasing out Aquinas's answer to these questions, Reichberg draws on the writings of a wide variety of figures associated with the just war tradition, including Augustine, Gratian, Cajetan, Vitoria, Suarez, Molina, Gentili, Grotius, Vattel, Walzer, Johnson, and McMahan. In doing so, he not only sheds fresh light on a host of controversial issues, such as the doctrine of double effect, preventive war, the moral equality of combatants, and Aquinas's jus ad bellum, he also bridges the divide between revisionist and traditionalist approaches to just war, demonstrating that, although they may sometimes present their arguments in different idioms, they are nevertheless tackling the same general problems. Many of the issues that divide just war theorists today were, Reichberg shows, also matters of some dispute in the Middle Ages. By revealing these continuities and bringing the views of Aquinas and his interpreters into conversation with McMahan and Walzer and their respective schools, Reichberg reminds us that behind today's fractious debates there is a fruitful dialogue about substantive issues to be had. In so doing, he does just war scholarship a great service.

It should not escape our attention, however, that the final chapter of Thomas Aquinas on War and Peace looks beyond these issues to engage the views of Pope John Paul II on the limits of just war. Even when it is justified, we are told, war is never a sufficient response to the problems that occasioned it, and it is always a defeat for humanity. Just war is, after all, just war, and, regardless of how refined or sophisticated our theories are, this will always be the case. 


\section{CONCLUSION}

There is a saying, often attributed to Bertrand Russell, that war does not determine who is right, only who is left. The books examined in this essay all recognize this fact, but, rather than viewing it as grounds for abandoning the idea of just war, they take it as a reason to think more carefully about it. As such, their efforts remind us that we should treat the claim that just war is just war not as a glib soundbite but as an inescapable irony that we must confront even as it makes a mockery of us all.

\footnotetext{
${ }^{1}$ Reinhold Niebuhr, The Irony of American History (Chicago: University of Chicago Press, 2008), p. 2.
}

${ }^{2}$ Ken Booth provides a neat encapsulation of this position. Just war theory, Booth writes, furnishes "a cover for war which allows power to do what power can do." If this is true, he adds, just war theory is "best seen as a continuation of war by other rhetoric." Ken Booth, "Ten Flaws of Just Wars," The International Journal of Human Rights 4, no. 3-4 (2000), p. 316-17. Also see: Andrew Fiala, The Just War Myth: The Moral Illusions of War (Lanham, MD: Rowman \& Littlefield, 2008).

${ }^{3}$ There is a parallel here to Wilfred Owen's angry rejection of the idea that it is a noble thing to die for one's country as an "old lie." Wilfred Owen, "Dulce et Decorum Est," Anthem for a Doomed Youth (London: Penguin, 2015), p. 2-3.

${ }^{4}$ Ian Clark, Waging War: A New Philosophical Introduction (Oxford: Oxford University Press, 2015), pp. $1-4$.

${ }^{5}$ Three recently published essays draw attention to the importance of how war is conceived in just war theory. Each one also argues in its own way that this fact has not always been adequately appreciated by just war theorists. Ian Clark, “Taking 'Justness' Seriously in Just War: Who Are the Sorry Comforters Now?” International Affairs 93, no. 2 (2017), pp. 327-41; Kimberley Hutchings, “War and Moral Stupidity," Review of International Studies 44, no. 1 (2018), pp. 83-100; and Chris Brown, "Revisionist Just War Theory and the Impossibility of a Moral Victory," in Andrew R. Hom, Cian O'Driscoll, and Kurt Mills, eds., Moral Victories: The Ethics of Winning Wars (Oxford: Oxford University Press, 2017), pp. 85-102.

${ }^{6}$ As Michael Walzer puts it, much contemporary just war theory is not about war, but about moral philosophy. Michael Walzer, Just and Unjust Wars: A Moral Argument with Historical Illustrations$5^{\text {th }}$ Edition (New York: Basic Books, 2015), p. 335. 
${ }^{7}$ On the nature of Walzer's just war theory: Chris Brown, "Michael Walzer", in Daniel R. Brunstetter and Cian O'Driscoll (eds.), Just War Thinkers; From Cicero to the $21^{\text {st }}$ Century (Abingdon: Routledge, 2017), pp. 20515.

${ }^{8}$ Quoted in Geoffrey Best, Humanity in Warfare: The Modern History of the Law of Armed Conflict (London: Methuen, 1980), pp. 6-7.

${ }^{9}$ Nicholas J. Rengger, Just War and International Order: The Uncivil Condition in World Politics (Cambridge: Cambridge University Press, 2013); Maja Zehfuss, War and the Politics of Ethics (Cambridge: Cambridge University Press, 2018). For a related and very interesting discussion, see James Eastwood, Ethics as a Weapon of War: Militarism and Morality in Israel (Cambridge:

Cambridge University Press, 2017).

${ }^{10}$ On the idea that realism can be treated in relation to political theory, see Sean Molloy, The Hidden History of Realism: A Genealogy of Power Politics (New York: Palgrave, 2006); and Matt Sleat, "Legitimacy in Realist Thought: Between Moralism and Realpolitik," Political Theory 42, no. 3 (2014), pp. 314-37.

${ }^{11}$ Joel H. Rosenthal, Righteous Realists: Political Realism, Responsible Power, and American Culture in the Nuclear Age (Baton Rouge: Louisiana State University Press, 1991).

${ }^{12}$ Frederick Russell, Just War in the Middle Ages (Cambridge: Cambridge University Press, 1975); James Turner Johnson, Ideology, Reason and the Limitation of War: Religious and Secular Concepts, 1200-1740 (Princeton; Princeton University Press, 1975).

${ }^{13}$ William Bain, ed., Medieval Foundations of International Relations (Abingdon: Routledge, 2017). 